\title{
Energy Analysis of Oklahoma Rangelands and Improved Pastures
}

\author{
J.M. KLOPATEK AND P.G. RISSER
}

\begin{abstract}
The energy costs of beef production were examined for native rangelands and improved pastures grazing systems in the State of Oklahoma. Energy analysis models were constructed to examine the necessary energy inputs and outputs of the grazing systems. Energy requirements to maintain improved pasture systems ranged from 10 to 100 times that to maintain native rangeland. Comparing only fossil-fuel expenditures showed that rangelands are two to three times more efficient producers of beef than the improved pastures, although their beef production is considerably lower per hectare. Regression analysis indicates that the maximum possible efficiency of beef production from fossil-fuel subsidies in Oklahoma is approximately $14.8 \%$.
\end{abstract}

Before the second half of the 20th century, cattle grazing operations of the southern plains were managed with virtually no fossilfuel-based energy input. With the advent of modern ranching, cattle grazing operations became more mechanized, sophisticated and thus, more dependent upon external sources of fuel and fuelbased supplies. Modern ranches not only depend on extensive transportation systems to move livestock and feed, but require machinery, gasoline, pesticides, fertilizers, and construction and maintenance supplies. The rapidly increasing cost of energy and fossil-fuel-based products is critical to the future of grazing operations. Thus, alternative methods of livestock production are being examined (e.g., Pimentel et al. 1980). A careful analysis is needed of the energy inputs required by various grazing operations so that choices of alternative systems are ultimately based on a full understanding of the energetics. Obviously beef production is related to energy outputs, but this relationship is influenced by a large number of variables such as grazing system, type of vegetation and livestock, climate, and prevailing economic conditions.

The purpose of this study was to examine the energy inputs and outputs of extensive and intensive cattle production systems. For this purpose two types of operations were selected: open rangeland and improved pasture. Three counties in Oklahoma were chosen to represent different vegetation and climate conditions. An energy analysis technique was used to compare the input and output of these livestock management systems in three geographically separate locations.

\section{Study Areas}

Texas, Cleveland, and McCurtain counties in Oklahoma (Fig. 1) were selected to illustrate grazing systems over a climate and vegetation continuum (Klopatek and Risser 1977). Descriptions of the biotic and abiotic features may be found in a number of publications (e.g., Davis 1960, Gray and Roozotilab 1975, Harlan 1960, Johnson and Risser 1974, McMurphy 1970, Rice 1965, Rice

\footnotetext{
At the time of the research, a uthors were with the Environmental Sciences Division, Oak Ridge National Laboratory, Oak Ridge, Tennessee 37830, and the Department of Botany and Microbiology, University of Oklahoma, Norman 73019. Currently, Klopatek is with the Department of Botany and Microbiology, Arizona State University, Tempe 85281, and Risser with the Illinois Natural History Survey, Champaign 61820. Research was supported in part by the Oklahoma Biological Survey, University of Oklahoma, and in part by the Office of Health and Environmental Research, U.S. Department of Energy, under contract W-7405-eng-26 with Union Carbide Corporation. Publication No. 1774, Environmental Sciences Division, ORNL. Manuscript reccived October 20, 1980.
}

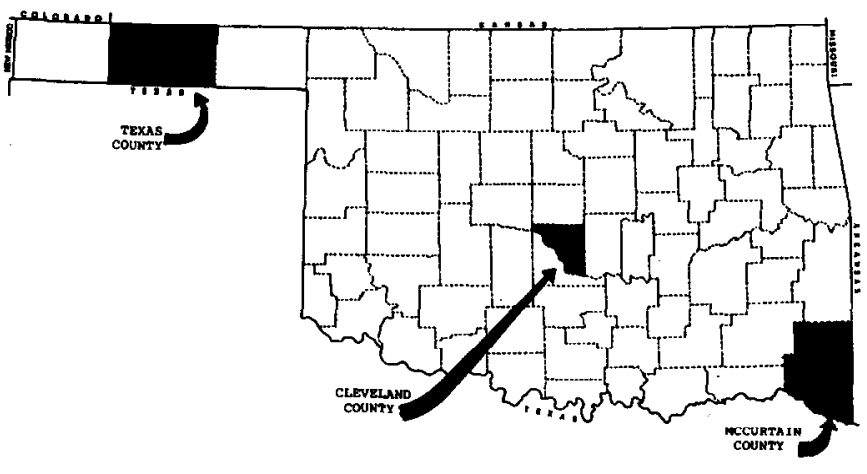

Fig. 1. Location of Texas, Cleveland, and McCurtain counties in Oklahoma.

and Penfound 1959, Risser et al. 1980b, Sternitzke and Sickel 1968, Wood and Burton 1968, Wood and Hart 1967).

Texas County, with an average precipitation of $45 \mathrm{~cm} /$ year, is primarily shortgrass plains (Duck and Fletcher 1945) dominated by blue grama (Bouteloua gracilis) and buffalograss (Buchloe dactyloides). The economic base for this sparsely populated county is agriculture, with $41 \%$ of the area classified as rangeland. Most of the remaining land is cropland, approximately one-third of which is irrigated from the underlying aquifer in the Oogallala Formation.

The average annual rainfall in Cleveland County is $87.6 \mathrm{~cm}$, and the vegetation is a mixture of Cross Timbers forest type of blackjack-post oak (Quercus marilandia- $Q$. stellata) and tallgrass prairie dominated by big bluestem (Andropogon gerardi), little bluestem (Schizachyrium scoparium), Indiangrass (Sorghastrum nutans), and switchgrass (Panicum virgatum). The county is becoming more urbanized (more than 60 people $/ \mathrm{km}^{2}$ ), but still supports wheat farming and beef cattle production.

McCurtain County is characterized by $192 \mathrm{~cm} /$ year average precipitation. This rainfall supports a diverse array of natural forest types (primarily oak-pine) and tallgrass prairie-hardwood savannas. More than one-half of the original forests have been cut and either planted to pine plantation or converted to rangeland or improved pasture.

\section{Methods}

To compare the energy inputs and outputs in the three counties, it was necessary to have a common analytical framework. Furthermore, a method was required by which many disparate items could be compared, such as beef production, solar energy, and cost of fertilizing improved pastures. Models and energy analysis techniques were used to address these evaluation requirements.

These models are hypotheses about the structure, function, and behavior of the grassland systems under consideration (Gilliland and Risser 1977). As such, they were useful in organizing information, guiding data collection, synthesizing ideas, comparing types of various impacts associated with the two grassland management 
strategies, and communicating the results of this rather complex investigation. The application of this systems analysis tool to the grazing practices was aimed at the macroscale or county level rather than at the individual ranch scale.

The problem discussed in this paper is made more complex but interesting because the grazing operations depend on both natural energy flow and various human-generated energy subsidies. The difficulty of analyzing a mixed natural and man-made system arises because of the structural complexity and the wide array of interacting forms of energy, materials, and other goods. The problem is first to convert goods, services, and natural energy into a common unit, and second to select the most reasonable unit to be used as a common comparator in those models addressing the specified question about two grazing practices in three counties.

Input/output (I/O) analyses (Herendeen and Bulla rd 1974, Frabetti et al. 1975, Alessio et al. 1978) were used to convert the economic costs of goods and services into energy equivalents. The economic and energy costs were obtained from the literature (sources are noted subsequently with the analyses). Economic and energy cost data from 1974 were employed in the analyses.

Energy conversion figures derived simply from $1 / O$ analyses fail to include the solar energy input in the total energy cost of producing a particular goods or service (Costanza 1978, Frabetti et al. 1975, Lavine and Meyburg 1976, Gilliland 1978). Placing a value on these natural processes requires the employment of an energy theory of value-a theory not without criticism by some (Slesser 1977, Georgescue-Roegen 1977). An energy theory of value is analogous to the concept of energy quality (Odum and Brown 1975 , Odum and Odum 1976). This concept recognizes that va rious types of energies (e.g., sunlight or gasoline) can accomplish different amounts of work. In accordance with the second law of thermodynamics for analyzing the quality of an energy source, the thermodynamic potential or free energy content is the important value, not the simple heat content. Thus, energy quality in this study is assumed to be a measure of the ability of an energy form to do work regardless of the specific application (e.g., gasoline, electricity, etc.).

Finally, it is necessary not only to establish that energy units will be used to compare man-made and natural processes but also to standardize the energy quality (ability to do work) values. The concept of kilocalories of fuel equivalents (Kcal FE) was chosen for this standardization. A fuel equivalent is calculated on the basis of the average national mixture of the nation's primary fuels. Conversion values were obtain from Herendeen and Bulla rd (1974). If all the kilocalorie measurements of energy resources are expressed in terms of kilocalories of fuel equivalents according to their energy equalities, then all the inputs and outputs of the system being evaluated can be compared on an equal basis.

An example of the use of energy quality conversion figures is as follows. Production of nitrogen fertilizer requires approximately $11,500 \mathrm{kcal}$ of energy per kilogram of nitrogen, of which 10,800 $\mathrm{kcal}$ comes from fossil fuel and $700 \mathrm{kcal}$ from electricity. However, approximately 3.89 energy units of fossil fuel (e.g., Btu) are required to make one unit (e.g., Btu) of electricity (Herendeen and Bullard 1974); thus, a total of $13,500 \mathrm{kcal}$ are required to produce a kilogram of nitrogen fertilizer. Therefore, the farmer who applies $100 \mathrm{~kg} / \mathrm{ha}$ of nitrogen to assist the planted corn to capture and concentrate the energy from sunlight has actually subsidized the system with $1,350,000 \mathrm{kcal} / \mathrm{ha}$ in the form of nitrogen fertilizer, in addition to other fuel-based subsidies in his cropland system. To convert kilocalories of sunlight to fuel equivalents, the conversion factor was $2000 \mathrm{kcal}$ of sunlight $=1 \mathrm{kcal}$ fuel equivalent (Odum and Odum 1976). Additional energy quality conversion factors are included in the Results and Discussion section.

The approach used in the study was to develop a generalized model for the grazing systems, rangeland and improved pasture. Then literature values were used to quantify the compartments and flows in each model. Once these numerical values were obtained and converted to the common base of kilocalories-fuel equivalents, it was possible to compare the input/output analyses resulting from each system. It should be emphasized at this point that the energy numbers and conversions used from a variety of sources are of varying quality. Some are well founded, based on physical laws, and agreed upon within a narrow range; others are empirically derived, have a wide range, and may be considered controversial. Thus, the reader should be aware that all the numbers reported here may not be considered as hard numbers, especially those energy values given to natural processes. However, emphasis is placed on those values that are fairly well documented which thus allows us a standardized basis for comparative purposes.

\section{Results and Discussion}

Energy models of the three counties provide a convenient framework from which comparisons can be made among the grassland systems (Figures 2, 3, and 4). Energy inputs can easily be separated into three groups: solar energy, fuel-based energy needed to maintain the range or improved pasture (FBEL), and fuel-based energy required to maintain and manage the livestock (FBEC) on each grassland type. In the following paragraphs FBEL include only those energies required to maintain the land for grazing whereas FBEC include those additional subsidies required by the addition of cattle to the grazing systems. Solar energy and rainfall subsidies are not controlled by the land manager, and their magnitudes are a

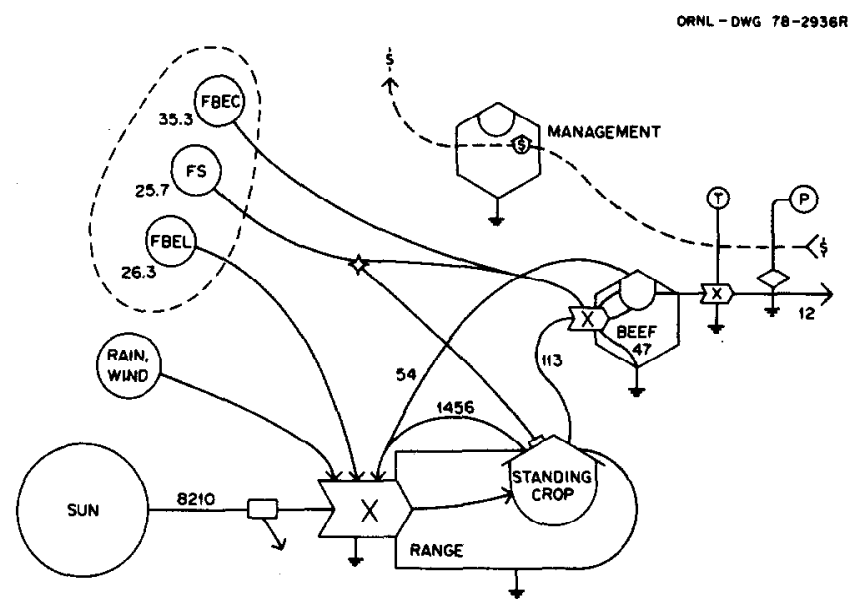

Texas County Ronge Model

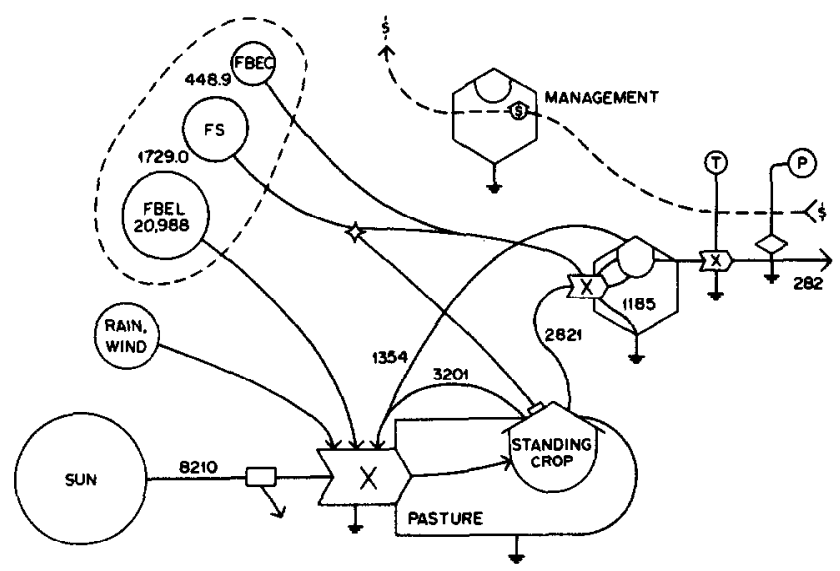

Texos County Posture Model

Fig. 2. Energy models of range and pasture systems in Texas County, Oklahoma. FS-food subsidy; FBEL-fuel-based energy subsidies for land maintenance; FBEC-fuel-based energy subsidies for cattle maintenance. Units. are $10^{3} \mathrm{kcal}$ fuel equivalents/hectare. 

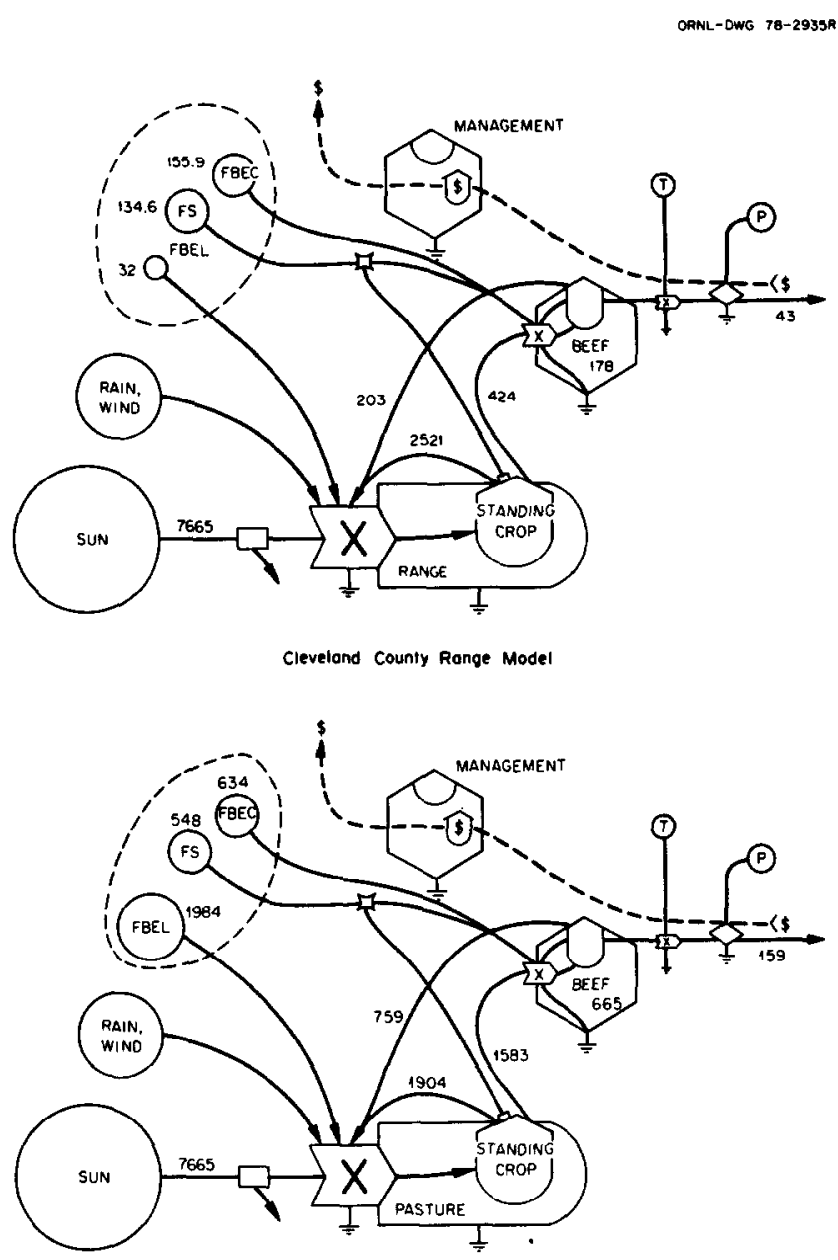

Cleveland County Posture Model

Fig. 3. Energy models of range and pasture systems in Cleveland County, Oklahoma. FS-food subsidy; FBEL-fuel-based energy subsidies for land maintenance; FBEC-fuel-based energy subsidies for cattle maintenance. Units are $10^{3} \mathrm{kcal}$ fuel equivalents/hectare.

function of the geographical location of the county. For example, the solar energy inputs $\left(10^{3} \mathrm{kcal}\right.$ fuel-based equivalents $\left./ \mathrm{ha}\right)$ for Texas, Cleveland, and McCurtain counties are 8210,7665, and 7300 , respectively. Although the natural energies input associated with rain, wind, etc., are depicted in Figs. 2-4, only the solar energy will be considered because of the often disparate techniques and resultant values for the accounting of "other" natural energies (Klopatek 1978, Odum et al. 1978).

\section{Energy Subsidies}

Fuel-based energy (FBEL) subsidies for maintaining the grasslands include: fuel and lub rication; fertilizer; machinery and equipment repair and depreciation; and irrigation. The percentage of these energy subsidies for the three counties is given in Table 1. Fuel-based energy subsidies to rangeland are relatively small (Table 2). Most of this energy is expended in control of undesirable vegetation, such as herbicide applications and mechanical brush control. On the other hand, energy subsidy required to maintain improved pastures, and the subsequent increased production, in these counties is comparatively much higher. In Texas County, most of the subsidies (88\%) are in the form of irrigation. In Cleveland and McCurtain counties, where rainfall is higher, most of the necessary subsidies (78-85\%) are in the form of fertilizer applications (Ward et al. 1977) to maintain the higher possible herbage production rates (McMurphy 1970).

Under simple rangeland grazing schemes, the amount of fuelbased energy to maintain the grassland is always less than $1 \%$ of the

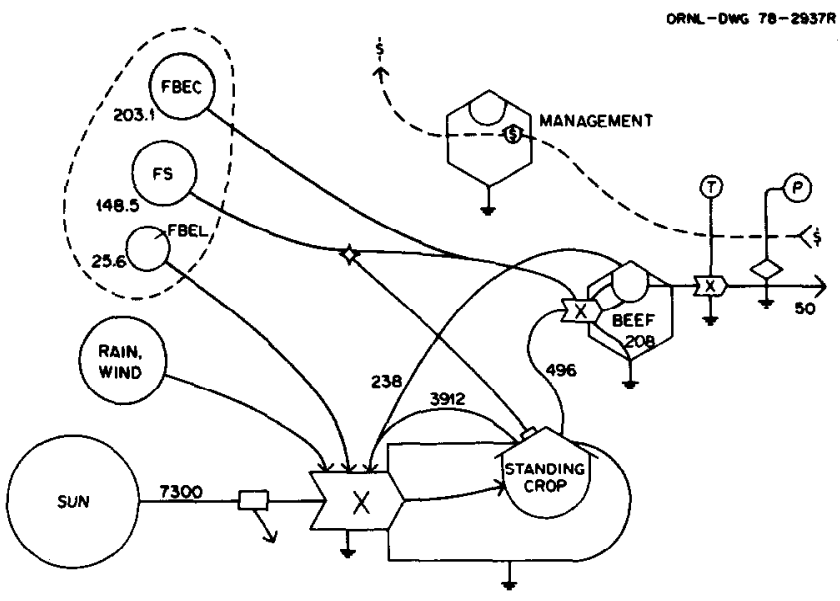

MeCurtain County Ronge Model

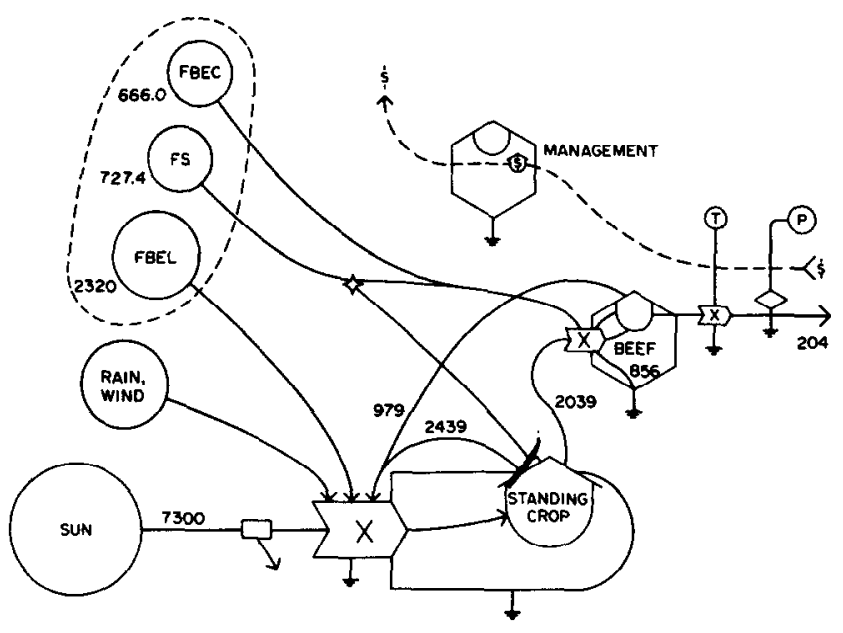

McCurtain County Pasture Model

Fig. 4. Energy models of range and pasture systems in McCurtain County, Oklahoma. FS-food subsidy; FBEL_fuel-based energy subsidies for land maintenance; FBEC-fuel-based energy subsidies for cattle maintenance. Units are $10^{3}$ kcal fuel equivalents/hectare.

total energy input (Table 2). However, under the managed pasture system, fuel-based energy subsidies are at least $29 \%$ (Cleveland County) of the total energy input, and in Texas County, $74 \%$ of the total energy input is in the form of fuel-based equivalents. Human labor was included in the analyses at an expenditure of $2 \times 10^{3} \mathrm{kcal}$ per hour (Klopatek 1978). Less than $1 \times 10^{3} \mathrm{kcal} \mathrm{FE} / \mathrm{ha}$ were expended in the range systems (e.g., fence upkeep and fertilizer applications) and 12,2 , and $3 \times 10^{3} \mathrm{kcal} \mathrm{FE} /$ ha for the managed pasture systems (for Texas, Cleveland, and McCurtain counties, respectively).

Maintaining and managing livestock requires considerable energy (Lockeretz 1975, Ward et al. 1977), but the actual magnitude of this expenditure is a function of many variables (e.g., grazing system, size of ranching operation, type of livestock, and supplementary feeding system). For the purpose of this study, livestock maintenance costs were based on a spring calving cowcalf operation (Okla. State Univ. 1975, Williams 1975). The fuelbased energy required to maintain each cow ranged from 450 to $675 \times 10^{3} \mathrm{kcal} \mathrm{FE} / \mathrm{ha}$ for the three counties. Because rangelands and improved pastures can maintain different stocking rates, it is useful to compare subsidies (FBEC) on the basis of both hectares and animals. The fuel-based energy requirements for maintaining an animal under rangeland conditions is roughly equivalent in all three counties (Fawcett 1975, Williams 1975, Okla. State Univ. 1975) (Table 3), but the cost per hectare is much greater in Cleveland and McCurtain counties because there are more animals per 
Table 1. Percentage of fuel-based energy (FBEL) for maintaining improved pastures in three counties according to fuel and lubrication, fertllzer, machinery and equipment repair and depreciation, and irrigation.

\begin{tabular}{lccc}
\hline \hline & \multicolumn{3}{c}{ Counties } \\
\cline { 2 - 4 } Type of FBEL subsidy & Texas & Cleveland & McCurtain \\
\hline Fuel and lubrication' & 1.4 & 14.9 & 6.6 \\
Fertilizer $^{2}$ & 9.3 & 77.8 & 85.5 \\
Machinery/equipment repair $^{3}$ & & & \\
$\quad \begin{array}{l}\text { and depreciation } \\
\text { Irrigation }\end{array}$ & 0.7 & 7.3 & 7.9 \\
\hline
\end{tabular}

'Diesel-9321 kcal FE/liter; oil-9312 kcal FE/liter.

2Fertilizer: N-13495 kcal FE/kg/ P-414 kcal FE/ kg/ K-414 kcal FE/ kg.

${ }^{3}$ Machinery and Equipment Repair: $9082 \mathrm{kcal}$ FE/ $\$$ (herendeen and Bullard, 1974). 4Machinery and Equipment Depreciation: $13742 \mathrm{kcal}$ FE/ \$ (Herendeen and Bullard 1974).

Irrigation: irrigation costs for maintenance of pasture were based on fuel- and machinery-related costs to irrigate alfalfa and small grains in Texas County.

hectare. Under the improved pasture scheme, the total subsidy cost on a pre-hectare basis is very high in Texas County (Table 3), primarily because of the necessity of food subsidies of protein supplement and hay. The rangeland and improved pasture systems were not markedly different in the energy required to maintain a single animal. However, calculated on the basis of hectares, cattle maintenance costs are much higher in the improved pasture system.
Considering total energy subsidies on the basis of hectares of rangeland and improved pasture, rangelands require less subsidy than improved pasture (Table 2). This difference is markedly different in Texas County where a very large energetic input is needed to maintain an improved pasture under dry climatic conditions. Under range conditions, solar energy subsidies contribute $95 \%$ or more of the total energy input. About two-third s of the total energy input to the improved pastures is solar energy energy in Cleveland and McCurtain counties, but only about $26 \%$ of the energy input is from natural sources in an improved pasture located in Texas County.

\section{Primary Production}

Data on primary production of grasslands used in this study (Table 4) were obtained from a study which compared primary production values from a number of grassland types across the country (including types represented in Texas, Cleveland, and McCurtain counties) (Singh and Josh 1980). The values closely approximate those obtained from other studies of primary production in the state of Oklahoma (Eck et al. 1975, Harlan 1960, Reigel 1947, Risser et al. 1980a).

Improved pastures in Oklahoma are planted to any one of several species, e.g., Bermudagrass (Cynodon dactylon), weeping lovegrass (Eragrostis currula), and several species of fescue (Festuca spp.). The grasses, especially with the addition of water and fertilizer, are more productive than native rangeland species (Cable 1971, Davies and Munro 1974, Risser et al. 1980, Rumsey 1971). In addition, the palatability of the introduced grass species is

Table 2. Natural and fuel-based energy subsidies required to maintain grassland and livestock on rangeland and improved pastures in Texas, Cleveland, and McCurtain counties, Oklahoma. Units are $10^{3} \mathrm{kcal}$ fuel equivalents per hectare.

\begin{tabular}{|c|c|c|c|c|c|c|}
\hline & \multicolumn{3}{|c|}{ Range } & \multicolumn{3}{|c|}{ Improved pasture } \\
\hline & Texas & Cleveland & McCurtain & Texas & Cleveland & McCurtain \\
\hline $\begin{array}{l}\text { Solar energy } \\
\text { Fuel-based energy to maintain }\end{array}$ & 8,210 & 7,665 & 7,330 & 8,210 & 7,665 & 7,330 \\
\hline $\begin{array}{l}\text { guel-based energy to maintain } \\
\text { Fusland }\end{array}$ & 26 & 32 & 26 & 20,988 & 1,984 & 2,320 \\
\hline $\begin{array}{l}\text { livestock' } \\
\text { Human labor }\end{array}$ & $\begin{array}{l}61 \\
<1\end{array}$ & $\begin{array}{l}291 \\
<1\end{array}$ & $\begin{array}{l}352 \\
<1\end{array}$ & $\begin{array}{r}2,178 \\
12\end{array}$ & $\begin{array}{r}1,182 \\
2\end{array}$ & $\begin{array}{r}1,393 \\
3\end{array}$ \\
\hline $\begin{array}{l}\text { Subtotal } \\
\text { (fuel-hased and human labor) } \\
\text { Total }\end{array}$ & $\begin{array}{r}87 \\
8.297\end{array}$ & $\begin{array}{r}317 \\
7.982\end{array}$ & $\begin{array}{r}378 \\
7,708\end{array}$ & $\begin{array}{l}23,178 \\
31,388\end{array}$ & $\begin{array}{r}3,168 \\
10,833\end{array}$ & $\begin{array}{r}3,716 \\
1,046\end{array}$ \\
\hline $\begin{array}{l}\text { Percent contributed by natural } \\
\text { energy }\end{array}$ & 99 & 96 & 95 & 31,500 & 71 & 66 \\
\hline
\end{tabular}

'Includes feed subsidy.

Table 3. Energy subsidization (kilocalories fuel equivalents $\times 10^{3}$ ) required for maintenance of cattle ${ }^{1}$ on rangeland and pastures in three Oklahoma counties. Values are for moderate stocking rates and range conditions.

\begin{tabular}{|c|c|c|c|c|c|c|}
\hline & \multicolumn{2}{|c|}{ Texas } & \multicolumn{2}{|c|}{ Cleveland } & \multicolumn{2}{|c|}{ McCurtain } \\
\hline & Per cow & Per ha & Per cow & Per ha & Per cow & Per ha \\
\hline \multicolumn{7}{|l|}{ Rangeland } \\
\hline $\begin{array}{l}\text { Fuel-based energy } 2 \\
\text { Food subsidy }{ }^{3}\end{array}$ & $\begin{array}{l}569 \\
414 \\
\end{array}$ & $\begin{array}{l}35 \\
26 \\
\end{array}$ & $\begin{array}{l}634 \\
547 \\
\end{array}$ & $\begin{array}{l}156 \\
1.35 \\
\end{array}$ & $\begin{array}{l}672 \\
492 \\
\end{array}$ & $\begin{array}{l}203 \\
149 \\
\end{array}$ \\
\hline Total & 983 & 61 & 1181 & 291 & 1164 & 352 \\
\hline \multicolumn{7}{|l|}{ Pasture } \\
\hline $\begin{array}{l}\text { Fuel-based energy }{ }^{2} \\
\text { Food subsidy }\end{array}$ & $\begin{array}{l}449 \\
846\end{array}$ & $\begin{array}{r}918 \\
1729\end{array}$ & $\begin{array}{l}632 \\
546\end{array}$ & $\begin{array}{l}727 \\
628\end{array}$ & $\begin{array}{l}451 \\
514^{4}\end{array}$ & $\begin{array}{l}666 \\
727^{4}\end{array}$ \\
\hline Total & 1295 & $\overline{2647}$ & 1178 & $\overline{1355}$ & 9965 & 1393 \\
\hline
\end{tabular}

'Figures do not include the fuel-based energy requirements for maintenance of rangeland or pastureland (see Table 2).

2Fuel-based energy (FBEC) includes energy for livestock supplies (conversion factor: 10,000 kcal FE/1974 S; compiled from Herendeen and Bullard 1974); machinery and equipment repair ( 9,082 kal FE/ 1974 \$; Herendeen and Bullard 1974, auto repair); machinery and equipment depreciation (13,742 kcal FE/1974 \$; Herendeen and Bullard 1974, farm machinery); fuel, gasoline $(9,321 \mathrm{kcal} F E /$ liter; lube, oil $9,312 \mathrm{kcal} \mathrm{FE} /$ liter). Human labor requirements are not included in the above totals but are listed in Table 2 . 3Protein supplements $(16,410 \mathrm{kcal}$ FE/ 1974 \$: Herendeen and Bullard 1974, prepared animal feed); grass hay (corrected for $85 \%$ moisture and $4.40 \mathrm{kcal} / \mathrm{g}$ dry wt); salt and minerals (16,410 kcal FE/ 1974 \$, same as protein supplements above).

"Includes energy costs of overseeding pastures with small grains and/or fescue in Fall. 
Table 4. Annual net (NPP) and gross (GPP) primary production (106 kcal/ ha) of range and improved pasture systems in Texas, Cleveland, and McCurtain counties, Oklahoma.

\begin{tabular}{|c|c|c|c|c|}
\hline \multirow[b]{2}{*}{ County } & \multicolumn{2}{|c|}{ Range } & \multicolumn{2}{|c|}{ Improved pasture } \\
\hline & NPP & GPPI & NPP & GPP \\
\hline $\begin{array}{l}\text { Texas } \\
\text { Cleveland } \\
\text { McCurtain }\end{array}$ & $\begin{array}{l}11.9 \\
23.6 \\
37.3\end{array}$ & $\begin{array}{l}31.3 \\
58.9 \\
88.2\end{array}$ & $\begin{array}{l}60.4 \\
34.9 \\
44.8\end{array}$ & $\begin{array}{r}120.4 \\
69.8 \\
89.6\end{array}$ \\
\hline
\end{tabular}

IGPP values for rangeland were obtained from Eck et al. (1975), Sims and Singh (1975), and Risser et al. (1980). GPP of pasture species was assumed to be twice that of Npp based on the data for rangeland and literature sources quoted in text. Texas County rangeland NPP $=38 \%$ GPP; thereforc NPP in fuel equivalents $=$ NPP kcal $\times$ $0.05 \div \mathrm{NPP} / \mathrm{Gpp}=\mathrm{NPP} \mathrm{kcal} \times 0.132$ or NPP kcal$/ 7.6=$ FE. Cleveland County $=\mathrm{NPP}$ $\mathrm{kcal} / 8$; McCurtain County $=$ NPP kcal $/ 8.4$. All pasture FE $=$ NPP kcal $/ 10$. The 0.05 multiplier value was obtained from Odum and Odum (1976).

improved over the nature species. Based on these studies the aboveground production approximation for improved pasture systems was twice that of the natural rangeland (Denmann et al. 1971). Net and gross primary production (GPP) estimates for pastureland in the three counties are shown in Table 4.

The total (above- and belowground) primary production differences in the improved pasture system as compared to the rangelands are obvious. Further, this difference (fivefold) is greatest in Texas County where irrigation is greatest. Also, it is noteworthy that in improved pastures the net primary production (NPP) is considered to be one-half the GPP. In the rangeland systems, NPP is 38 to $42 \%$ of GPP (Table 4). This narrowing of the difference between NPP and GPP is caused both by energy subsidies and by breeding improved strains which channel selectively more energy into NPP and less into plant maintenance activities.

\section{Animal Production}

Both rangeland and improved pastures are primarily managed to support livestock. The principal type of livestock in these three counties is beef cattle, but there are also milk cows, sheep, hogs, and horses (Table 5). Actual consumption of herbage depends on a number of factors such as the grazing system, vegetation composition, and characteristics of the grazing animals. Two grazing systems may have the same annual NPP, but quite different AUM-s AUM = animal unit months, the amount of feed/forage considered as required to maintain one mature animal $(454 \mathrm{~kg})$ for one month. In this analysis one AUM is considered to be $1.5 \times 10^{6} \mathrm{kcal}$ gross energy $(9 \mathrm{~kg} / \mathrm{d}$ dry matter intake) based on data extracted from Garrett (1974) and Heath et al. (1973).
Estimates of herbage production for the rangelands of the three counties were derived from Dyck and Bement (1971), Harlan (1960), and Rice et al. (1971); improved pasture estimates cam from Fawcett (1975), Garrett (1974), Okla. State Univ. (1975) and Williams (1975). The calculated amount of herbage consumed was based on the assumption of a moderate cattle-stocking rate with an average per-animal weight gain for each of the counties (Table 6). The energy balances for the livestock (Barrick and Dobson 1973, Dean et al. 1975, Garrett 1974, Hyder et al. 1971, Rice et al. 1971, Wilson and Burns 1973) were approximated as follows: $54 \%$ of the forage intake was lost through fecal, urinary, and methane output, $38 \%$ lost in respiration, and $2 \%$ lost in metabolic heat. Although this suggests $6 \%$ of the forage intake is converted to biomass, an upper value of $10 \%$ was approximated because of the more efficient utilization of supplemental feeds by cattle (lower efficiency or higher consumption due to lactation were not included).

\section{Energy Efficiency}

Having estimated energy costs to maintain the grasslands and cattle and the beef output, it is now possible to compare the energetic efficiencies of the two grazing systems in the threc counties. Although there are a number of ways of calculating efficiency, we are using it as a measure of output divided by input. This measure is used throughout this paper. A number of points arise from this analysis (Table 7). If efficiency of energy capture is considered to be simply the ratio of secondary production (beef production) to primary production (herbage available for consumption), the rangelands are approximately two to three times more efficient than the improved pastures. However, based only on the solar energy input to these grassland systems, the rangelands are considerably less efficient than the pastures. The greater efficiency of the improved pastures indicates the success of plant breeding and management in developing systems which more effectively capture and utilize solar energy. If the returns are calculated just on the basis of fuel-based subsidies, the ratio (output/input) is slightly greater than $13 \%$ in all the rangelands. Improved pastures are actually less efficient using fuel-based subsidies, least in dry Texas County and increasing in the more moist Cleveland and McCurtain counties. When all the natural and fuel-based energy subsidies are compared to the beef output (that is beef output to total energy input), the improved pastures are more efficient than the rangelands, and among the improved pastures, those in McCurtain County are the most efficient in energy capture and exploitation.

Because the ratio of beef output to fuel-based subsidies is approximately the same in rangeland found in all three counties,

Table 5. Numbers of livestock in Texas, Cleveland, and McCurtain counties (as of January 1, 1975).

\begin{tabular}{|c|c|c|c|c|c|}
\hline & Cattle & Milk cows & Sheep & Hogs & Horses and mules \\
\hline $\begin{array}{l}\text { Texas } \\
\text { Cleveland } \\
\text { McCurtain } \\
\text { State total }\end{array}$ & $\begin{array}{r}277,000 \\
32,000 \\
61,000 \\
6,020,000\end{array}$ & $\begin{array}{r}500 \\
1,700 \\
600 \\
126,000\end{array}$ & $\begin{array}{r}550 \\
700 \\
350 \\
104,000\end{array}$ & $\begin{array}{r}4,800 \\
3,200 \\
600 \\
315,000\end{array}$ & $\begin{array}{r}2,500 \\
5,600 \\
5,300 \\
230,000\end{array}$ \\
\hline
\end{tabular}

Table 6. Average annual available energy (104 kcal), animal unit months (estimated as $\left.1.5 \times 10^{6} \mathrm{kcal}\right)$, average weight gain (kg), and beef output (103 $\mathrm{kcal}$ fuel equivlents) for cattle at moderate stocking rates on rangeland and improved pastures in Texas, Cleveland, and McCurtain counties, Oklahoma. Tabular values are expressed as per year per hectare.

\begin{tabular}{|c|c|c|c|c|c|c|}
\hline \multirow[b]{2}{*}{ Category } & \multicolumn{3}{|c|}{ Range } & \multicolumn{3}{|c|}{ Improved pasture } \\
\hline & Texas & Cleveland & McCurtain & Texas & Cleveland & McCurtain \\
\hline Available energy & 1.0 & 3.4 & 4.1 & 28.2 & 15.8 & 20.4 \\
\hline Animal unit month & 0.9 & 2.9 & 3.6 & 24.5 & 13.8 & 17.7 \\
\hline Weight gain & 47.0 & 178.0 & 208.0 & 1185.0 & 178.0 & 856.0 \\
\hline Beef output & 12.0 & 43.0 & 50.0 & 282.0 & 159.0 & 204.0 \\
\hline
\end{tabular}


Table 7. Percent efficiency of beef output compared to energy subsidization in rangelands and improved pastures of Texas, Cleveland, and McCurtain counties, Oklahoma. Tabular values are calculated on the basis of fuel equivalents. Values used to derive ratios are depicted in figures 2 , 3 and 4.

\begin{tabular}{|c|c|c|c|c|c|c|}
\hline \multirow[b]{2}{*}{ Output/input } & \multicolumn{3}{|c|}{ Range } & \multicolumn{3}{|c|}{ Improved pasture } \\
\hline & Texas & Cleveland & McCurtain & Texas & Cleveland & McCurtain \\
\hline Beef output & 0.77 & 1.46 & 1.13 & 0.47 & 0.46 & 0.46 \\
\hline $\begin{array}{l}\text { Primary production } \\
\text { Beef output }\end{array}$ & 0.14 & 0.56 & 0.68 & 3.43 & 2.07 & 2.78 \\
\hline $\begin{array}{l}\text { Natural energy } \\
\text { Beef output } \\
\text { Fuel-based subsidies }\end{array}$ & 13.8 & 13.3 & 13.2 & 1.2 & 4.6 & 7.5 \\
\hline $\begin{array}{l}\text { Fuel-based subsidies } \\
\text { Beef output } \\
\begin{array}{l}\text { Natural energy \& fuel- } \\
\text { based subsidies }\end{array}\end{array}$ & 0.14 & 0.54 & 0.65 & 0.90 & 1.47 & 1.85 \\
\hline
\end{tabular}

there is the suggestion that there is a baseline conversion efficiency in the Oklahoma grasslands. This efficiency is approximately 7.5 units (Kcal FE) of fossil-fuel expenditures for every one unit (Kcal $\mathrm{Fe})$ of beef produced [or approximately $4.2 \mathrm{lb}(1.1 \mathrm{~kg})$ ], regardless of the grassland type. If the energy lost in dressing the beef is used (NSF 1977), the ratio is about 15 to 1. For comparison, the ratio of energy produced from agricultural crops to fossil-fuel expenditures is about 1.6. Energetically, therefore, fossil-fuel expenditures for a unit of beef are roughly 4.5 times greater than those for a unit of agricultural crops (on a dry weight basis).

The use of fuel-based subsidies increases the utilization of natural energy, so as beef production increases, sodoes the efficiency of beef output to natural energy. A more interesting point emerges, however, when beef production is compared with the efficiency of

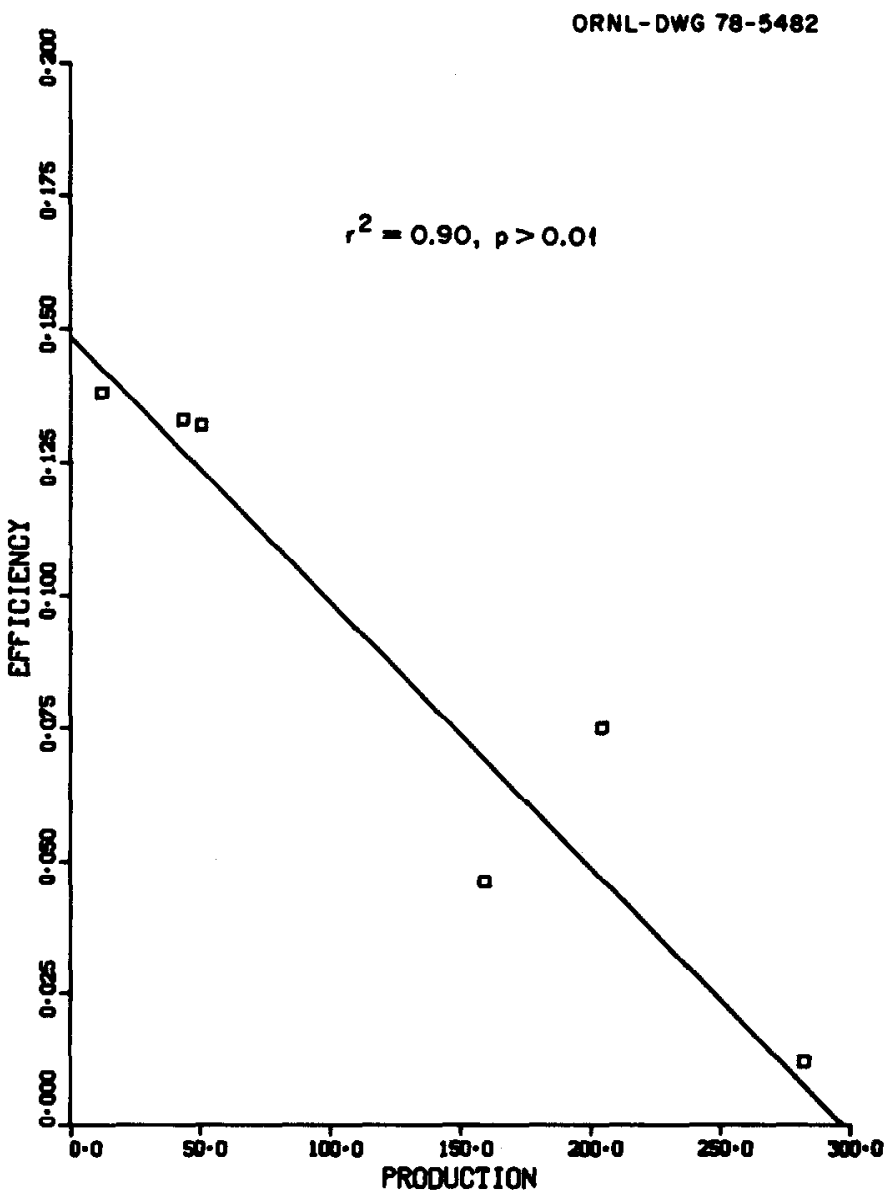

Fig. 5. Comparison of beef production (in kcal fuel equivalents) to percent efficiency in range and improved pasture systems in Texas, Cleveland, and McCurtain counties, Oklahoma. fuel-based subsidies. As the beef production increases, the efficiency of fuel-based subsidies decreases (Fig. 5). The Y intercept of this linear regression is $14.8 \%$ which indicates that this is the current maximum possible efficiency of beef production to fossilfuel subsidies in Oklahoma grassland systems. This means that the best ratio of returns on fuel-based subsidies is $1 \mathrm{kcal}$ of beef for every $6.76 \mathrm{kcal}$ of subsidy. Although beef production is higher in improved pastures, the ratio of fuel-based subsidies to beef output is $83.8,21.0$, and 18.6, respectively, for Texas, Cleveland, and McCurtain counties. Thus the cost of fuel subsidies for improved pastures in Texas County, principally irrigation costs, is great when compared to those in Cleveland and McCurtain counties.

\section{Conclusions}

The proportion of energy required to maintain grasslands is relatively small on rangelands, but 10 to 100 times greater using the improved pasture management regime. Similarly, energy required to manage range livestock is four times greater with the improved pasture system. Natural energy inputs comprise $95 \%$ of the total in rangeland grazing systems, but much less of the total on improved pastures, especially where irrigation needs are severe. Although the direction of the relative costs are obvious, the comparative quantification requires a conceptual framework and a common value for comparison.

Both rangelands and improved grasslands are relatively inefficient in capturing natural energy and utilizing fuel-based energy. The relative efficiencies, however, are not clear until the basis of comparison is classified. The foregoing analysis has shown that fuel-based subsidies enhance the grazing system's capacity to make use of the natural or solar energy, but that there is an upper limit to the ratio of beef production that can be obtained for fuel-based inputs. This limit is constant on rangelands regardless of the climatic conditions over the range we tested, but is affected by climatic conditions prevailing over improved pastures.

Consideration of future growing management alternatives requires a clear understanding of the role of natural and fuel-based energy subsidies and of the interaction between the two as a function of grazing system, vegetation, and climate. Energy analysis models have been shown to provide the analytical framework to address these questions.

\section{Literature Cited}

Alessio, F.J., B.L. Jackson, and D.B. Cohen. 1978. An appraisal of energy analysis. EPRI-EA-504. Electric Power Research Institute, Palo Alto, California. $114 \mathrm{p}$.

Barrick, E.R., and S.H. Dobson. 1973. Forage land-use efficiencies with commercial cattle. p. 690-702. In: M. Heath, D. Metcalfe and R. Barnes (eds.), Forages-The Science of Grassland Agriculture. Third edition. lowa State Univ. Press, Ames, lowa.

Cable, D.R. 1971. Lehmann lovegrass on the Santa Rita Experimental Range, 1937-1968. J. Range Manage. 24:17-21. 
Costanza, R. 1978. Energy costs of goods and services in 1967 including solar energy inputs and labor and government services feedbacks. Energy Research Group Doc. No. 262. Center for Advanced Computation, Univ. of Illinois, Urbana, Illinois. 46 p.

Davis, L.V. 1960. Gcology and groundwater resources of southern McCurtain County, Oklahoma. Okla. Geol. Surv. Bull. 86, Norman, Okla. $108 \mathrm{p}$.

Davies, D.A., and J.M.M. Munro. 1974. Potential pasture production in the uplands of Wales. 4. Nitrogen response from sown and natural pasture. J. Br. Grassl. Soc. 29:149-158.

Dean, R., J.E. Ellis, R.W. Rice, and R.E. Bement. 1975. Nutrient removal by cattle from a short-grass prairie. J. Appl. Ecol. 12:25-29.

Denmann, C.E., W.W. Huffine, and J.D. Arnold. 1971. Bermuda grass forage production studies in Oklahoma, 1962-1970. Okla. Sta. Univ. Agri. Exp. Sta, Bull. B-692, Stillwater, Okla.

Duck, L.G., and J.B. Fletcher. 1945. A survey of the game and fur-bearing animals of Oklahoma. Oklahoma Game and Fish Comm. PittmanRobinson Series No. Il. State Bull. No. 3. Oklahoma City, Okla. 144 p.

Dyck, G.W., and R.E. Bement. 1971. Herbage growth rate, forage intake, and forage quality in 1970 on heavily and lightly grazed blue-grama pastures. US IBP Grassland Biome. Tech. Rep. No. 94, Colorado State Univ., Fort Collins, Colo. 14 p.

Eck, H.V., W.G. McCully, and J. Stubbendieck. 1975. Response of shortgrass plains vegetation to clipping, precipitation, and soil moisture. J. Range Manage. 28:194-197.

Fawcett, D. 1975. Crop and livestock budgets-Northwest Oklahoma. Okla. State Univ. Agr. Ext. Serv., Stillwater, Okla.

Frabetti, A.J., C.. N. Flinkstrom, M. Garden, R.A. Lovell, Jr., C. Sheldon III, J.D. Westfield, and P.F. May. 1975. A study to develop energy estimates of merit for selected fuel technologies. Report to U.S. Department of Interior by Development Sciences, Inc. National Technical Information Service, Springfield, Virginia. 376 p.

Garrett, W.N. 1974. Estimation of the nutritional value of feeds. p. 501514. In: H.H. Cole and M. Ronning (eds.), Animal Agriculture. The Biology of Domestic Animals and Their Use by Man. W.H. Freeman and Co., San Francisco. $788 \mathrm{P}$.

Georgescu-Roegen, N. 1977. The steady state and ecological salvation: A thermodynamic analysis. BioScience 27:266-271.

Gilliland, M.W., and P.G. Risser. 1977. The use of systems diagrams for engironmental impact assessment: Procedures and application. Ecol. Model. 3:183-210.

Gilliland, M.W. (ed.). 1978. Energy Analysis: A New Public Policy Tool. Proceedings of AAS Symposium, Denver, Colorado, January 1976. Westview Press, Boulder, Colo.

Gray, F., and A. Roozotilab. 1975. Benchmark soils of Oklahoma. Oklahoma State Univ. Agri. Exp. Sta. Bull. B898. Stillwater, Okla.

Harlan, J.R. 1960. Grasslands of Oklahoma. Oklahoma State University, Stillwater, Okla. 160 p.

Heath, M.E., D.S. Metcalfe, and R.F. Barnes (eds). 1973. Forages: The Science of Grassland Agriculture. Third Ed. Iowa State Univ., Press, Ames, lowa. 755 p.

Herendeen, R.L., and C.U. Bullard, III. 1974. Energy cost of commerce goods, 1963 and 1967. CAC Document No. 140, Center for Advanced Computation, Univ, of Illinois, Urbana-Champaign, Ill.

Hyder, D.N., K.L. Knox, and C.L. Streeter. 1971. Metabolic components of cattle under light and heavy rates of stocking in 1970. US IBP Grassland Biome. Tech. Rep. No. 128. Colorado State Univ., Fort Collins, Colo. 42 p.

Johnson, F.L., and P.G. Risser. 1974. Biomass, annual net primary production and dynamics of six mineral elements in a post oak-blackjack oak forest. Ecology 55:1246-1258.

Klopatek, J.M. 1978. The energetics of land use in three Oklahoma Counties. Ph.D. Diss. Univ. of Oklahoma, Norman, Okla. 246 p.
Klopatek, J.M., and P.G. Risser. 1977. Primary productivity profile of Oklahoma. Okla. Bio. Surv. Special Pub. Norman, Okla, 188 p.

Lavine, J.J., and A.H. Meyburg. 1976. Toward environmental benefit / cost analysis: Measurement methodology. National Cooperative Highway Research Program, National Research Council, Washington, D.C. 107 p. + appendices.

Lockeretz, W. 1975. Consumption of agricultural resources in the production of fat cattle and foodgrains. J. Soil Water Conserv. 39:268-27I.

McMurphy, W.E. 1970. Fertilization and deferment of a natural hay meadow in northcentral Oklahoma. Okla. Agric. Exp. Sta. Bull. 13-678. Okla. State Univ., Stillwater, Okla.

National Science Foundation (NSF). 1977. Back to the range. Mosaic 8:23-28.

Odum, H.T., F.C. Wang, J. Alexander, and M.W. Gilliland. 1978. Energy analysis of environmental values. Tech. Progress Rep. Nuclear Regulatory Comm. NRL-04-077-123. Univ. of Florida, Gainesville, Fla. 172 p.

Odum, H.T., and M.T. Brown (es.). 1975. Carrying Capacity for Man and Nature in South Florida. Center for Wetlands, Univ. of Florida, Gainesville, Flor. 887 p.

Odum, H.T., and E.C. Odum. 1976. Energy basis for man and nature. McGraw-Hill, New York 297 p.

Oklahoma State University Extension Service. 1975. Crop and livestock budgets-central Oklahoma. Stillwater, Okla.

Pimentel, D., P.A. Oltenacu, M.C. Nesheim, J. Krummel, M.S. Allen, and S. Chick. 1980. The potential for grass-fed livestock: Resource constrains. Science 207:848-848.

Rice, E.L. 1965. Bottomland forests of northcentral Oklahoma. Ecology 46:708-714.

Rice, E.L., and W.T. Penfound. 1959. The upland forests of Oklahoma. Ecology 40:593-608.

Rice, R.W., J.G. Nagy, and D.G. Peden. 1971. Functional interaction of large herbivores on grasslands. p. 241-265. In: N.R. French (ed.), Preliminary Analysis of Structure and Function in Grasslands. Range Science Department, Science Ser. No. 10. Colorado State University, Fort Collins, Colo. 387 p.

Riegel, A. 1947. Forage yields of various native pasture grasses established artificially at Hays, Kansas, in 1941. Trans. Kans. Acad. Sci. 50:174-190.

Risser, P.G., E.C. Birney, H.D. Blocker, W.S. May, W.J. Parton, and J.A. Wiens, 1980a. The True Prairie Ecosystem. Dowden, Hutchinson, and Ross, Stroudsburg, Pennsylvania. (In press).

Risser, P.G., J.H. Risser, and V. Goodknight. 1980b. Unique ecosystems concept plan for Oklahoma. U.S. Fish and Wildlife Service, Albuquerque, New Mexico.

Rumsey, W.B. 1971. Range seedings versus climax vegetation on three sites in Idaho. J. Range Manage. 24:447-450.

Singh, J.S., and M.C. Josh. 1980. Primary production. In: Grassland Ecosystems of the World: Analysis of Grasslands and Their Uses. R.T. Coupland (ed.), Cambridge Univ. Press, London (in press).

Slesser, M. 1977. Energy a nalysis (letter to the editor). Science 196:260-261.

Sternitzke, H.S., and C.C. Van Sickle. 1968. East Oklahoma forests. USDA Forest Service Publication. Southern Forest Experiment Station, New Orleans, Louisiana. 32 p.

Ward, G.M., P.C. Knox, and B.W. Hobson. 1977. Beef production options and requirements for fossil fuel. Science 198:265-271.

Williams, G. 1975. Crop and livestock budgets-Southeast Oklahoma. Okla. Sta. Univ. Agri. Ext. Serv., Stillwater, Okla.

Wikon, L.L., and J.C. Burnms 1973. Utilization of forages with beef cows and calves. p. 677-689. In: M. Heath, D. Metcalfe, and R. Barnes (eds.), Forages-The Science of Grassland Agriculture. Third ed. lowa State Univ. Press, Ames, Iowa.

Wood, P.R., and D.L. Hart, Jr. 1967. Availability of groundwater in Texas County, Oklahoma. U.S. Geol. Survey. Hydro. Invest. Atlas HA-250.

Wood, P.R., and L.C. Burton. 1968. Groundwater resources in Cleveland and Oklahoma counties. Okla. Geol. Survey Circ. 71, Norman, Okla. 75 p. 